\title{
Certification proposal for the traditional professional cook of the state of Puebla
}

\section{Propuesta de certificación para las cocineras tradicionales del estado de Puebla}

\author{
PEREA-BALBUENA, José Ángel†๋, CARRASCO-ROMERO, Víctor Josaphat and ZAMORA \\ FERNANDEZ, María de los Dolores
} Benemérita Universidad Autónoma de Puebla, Facultad de Administración. 4 Sur \#104; Col. Centro C.P. 72000; Puebla de
Zaragoza, Puebla, México

ID $1^{\text {st }}$ Author: José Ángel, Perea-Balbuena / ORC ID: 0000-0002-1868-4450, CVU CONACYT ID: 913019

ID $1^{\text {st }}$ Coauthor: Víctor Josaphat, Carrasco-Romero / ORC ID: 0000-0001-6395-3608, CVU CONACYT ID: 450396

ID $2^{\text {nd }}$ Coauthor: María de los Dolores, Zamora-Fernandez / ORC ID: 0000-0003-1347-8348, CVU CONACYT ID: 419364

DOI: $10.35429 / J L D E .2019 .4 .3 .14 .24$

Received February 21, 2019; Accepted June 29, 2019

\begin{abstract}
Eating is a biological act and cooking, a cultural act; the gastronomy in Mexico, for the culinary variety is the third in the world. The cuisine is made up of indigenous, spanish and asian elements, making it one of the most representative of the country, which consolidates its legitimate pride of identity. A good part of tourism moves, to a large extent, in search of gastronomic delights, find these in the typical markets of a province, a place or a good inn; allowing to interact with the popular gastronomic identity. The objective is to create a certification for the traditional professional cook of the markets of the city of Puebla in order to have the knowledge and technical tools to offer food with the best possible quality, thus allowing to generate an identity of gastronomic culture. In order to substantiate this certification, a study was carried out in the markets of the city having generated results that allowed the realization of the first training courses, which shall lay down the basis for the relevant certification. The kitchens in Puebla, have been laboratories of the food culture, the traditional professional cook, possess a culinary knowledge that contribute to the intangible cultural heritage, for this reason it is necessary that they possess a certification that gives them certainty of value in the activities that they carry out to frame in food identity.
\end{abstract}

Culture, Traditional Professional Cook, Certification

\begin{abstract}
Resumen
Comer es un acto biológico y cocinar, un acto cultural; la gastronomía en México, por su variedad culinaria es la tercera en el mundo. La cocina poblana está conformada por elementos indígenas, españoles y asiáticos, haciéndola una de los más representativos del país, que consolida su legítimo orgullo de identidad. Buena parte del turismo se desplazan, en gran medida, en busca de delicias gastronómicas, encuéntrense estas en los mercados típicos de una provincia, un paraje o una buena fonda; permitiendo interactuar con la identidad gastronómica popular. El objetivo es crear una certificación para las cocineras tradicionales de los mercados de la ciudad de Puebla a fin de contar con los conocimientos y herramientas técnicas para ofrecer alimentos con la mejor calidad posible, permitiendo así generar una identidad de cultura gastronómica. A fin de fundamentar esta certificación se realizó un estudio en los mercados de la cuidad habiendo generado resultados que permitieron la realización de los primeros cursos de capacitación, que asentarán las bases para la certificación correspondiente. Las cocinas en Puebla, han sido laboratorios de la cultura alimentaría, las cocineras poblanas, poseen un conocimiento culinario que aportan al patrimonio cultural inmaterial, por tal motivo es necesario que sean poseedoras de una certificación que les de certeza de valor en las actividades que realizan para enmarca en identidad alimentaria.
\end{abstract}

Cultura, Cocinera Tradicional, Certificación

Citation: PEREA-BALBUENA, José Ángel, CARRASCO-ROMERO, Víctor Josaphat and ZAMORA FERNANDEZ, María de los Dolores. Certification proposal for the traditional professional cook of the state of Puebla. RINOE Journal- Labor and Demographic economic. 2019. 3-4: 14-24.

\footnotetext{
* Correspondence to Author (email: perea_angel@ @otmail.com)

$\dagger$ Researcher contributing first author.
} 


\section{Introduction}

Gastronomy in Mexico, for its culinary variety and tradition, is the third in the world and is a product of the miscegenation of indigenous, Spanish and Asian elements, which has been considered as one of the most representative of the country. The basis of this meal is corn, beans, chili and squash, ingredients that combine to produce a variety of dishes. It is said, with truth, that eating is a biological act and cooking, a cultural act.

Therefore, culture, which is not abstraction but concrete data expressed through the creative capacity of humans, is an accumulated wealth that has been building the planet in a hopeful and civilizing humanity, which has given societies formulas to live together and develop in all dimensions, both material and spiritual. In this sense, food is intimately linked to rituals and parties, so that its elaboration constitutes to honor humans and gods. Therefore, the archeology of food has documented the consumption of a wide variety of food products through the analysis of remains in comales, which reveal in them the preparation, for food, of products from the animal and plant kingdom.

It should be noted, the light of a culture is radiated by its multiple manifestations: music, architecture, sculpture, painting, and not to a lesser extent, the intimate dimension of everyday life; especially, the act of permanent love, repeated every day, which is cooking.

In this way, the kitchen is represented as a maximum expression of culture that, while infusing biological life to the individual, consolidates its legitimate pride of identity.

Food, species and condiments, as a whole have given rise to gastronomic discipline and have made changes to all civilizations throughout history. Food and nutrition are essential properties of life, there is no living organism without food. But man is the animal that cooks, the only being that transforms that instinctive activity into a mental exercise. Yes Aristotle defined us immortally as "social animals", the famous gourmet Faustino Cordón points out that, before social animals we have been "culinary animals". Cooking not only made man: he made it social.
The setting up of Faustino Cordón is interesting since, in the process of supply, preparation and consumption of food, they have made each social group create their own identity in relation to their diet.

Food, in addition to being an act of eating, has given a deep sense of belonging to a social group, that's why we consider the enormous civilizing role of cooking in human history

\section{Justification}

A good part of tourism travels, to a large extent, in search of gastronomic delights, find where they are: be it in the market of a lost province; in a place where there is nothing more, but nothing less, than a good inn; or in a truckers restaurant on the edge of a route.

Therefore, gastronomy is the art of turning food into joy. For her to exist, it is necessary to have created a kitchen in permanent evolution. Mexican cuisine flows through a large channel and has its main currents:

a) The indigenous, pre-Hispanic primitive kitchens, corresponding to the diverse cultures that existed in Mesoamerica. This is where the mother recipes of our culture are found.

b) The contributions of foreign cuisines, from the Caribbean to the Hispanic ones, with their Arab and Jewish trasiegos.

c) The permanent evolution of Mexican cuisine, is when the two previous items merge and create the true, unique, Mexican cuisine.

The reflections on gastronomy and how it is built are expressed in three postulates:

1. Each kitchen has its own spirit, integrated by a set of rules that identify and characterize it

2. The kitchen originates in a geographical area determined by its land, sky and its men.

3. A kitchen can be different and be differentiated by the set of their dishes.

According to Pérez San Vicente, every kitchen must comply with the following statements: 
a) Being born in their own territory, determining their own space.

b) Having created their own utensils.

c) Produce your own inputs.

d) Invent your ways and ways of cooking.

e) Have your repertoire of dishes that cover every range of flavors: from sweet sour, from rough to soft, from salty to bitter.

f) Be conceived by genres that integrate all the steps of a meal.

g) Having established their schedules, customs and labels.

h) The taste for the dish must exceed, at least, three generations, that is, more or less 150 years.

i) Being able to take advantage of the knowledge of other people's cuisine to incorporate them without distorting their spirit.

j) Having created dishes that identify you internationally.

Through the genesis of history, women have been assigned the responsibility of domestic food as a constitutive element of femininity. They appear as the main culinary transmitters of the Mexican peoples, in which their persistence in keeping memory alive, places them as bearers of knowledge and flavors of a gastronomic past and present.

Therefore, Puebla has consolidated over time as a region of the country whose cuisine is appreciated by own and strangers. In this gradual process, different real and imaginary contributions acrisolaron a gastronomic offer of Creole and mestizo nature, whose aromas and flavors are considered of baroque sensitivity.

Culinary fame has also spread in other ways, through the ingenuity of chroniclers and writers, who have built the history of some dishes using legends, full of romanticism. It should be noted that the food was made under the ingenuity of poblano cooks, to conquer the palate of family and friends.
Therefore, the kitchens in Puebla, have been laboratories of food culture, which integrates dishes, which offer succulent combinations; as well as broths, mole, marrow soup, chiles en nogada, marinades and drinks; In addition to cravings, such as: toasts, cemites, chalupas and molotes that emerge for our entertainment and palate, which is part of the food geography.

However, the anonymous cooks of homes, markets and convents continue to preserve and transmit knowledge through their recipes, which are part of the memory and cultural heritage that are framed in family ties. It is worth mentioning that the poblano cooks have a culinary knowledge that they contribute to the intangible cultural heritage, which is framed in food identity.

In addition, the cooks have not only nourished our population, but they have been a therapeutic resource, when they produce products for specific diets for the sick or convalescent, as is the case with atoles.

It is important to highlight that, in 2010, Mexican gastronomy was declared Intangible Cultural Heritage of Humanity-UNESCO, since it demonstrates some antiquity and historical continuity, it also enjoys an important role as an identity element, it is of collective elaboration, which It relies on products originating in its land and boasts great creativity in its cooks, which over the centuries have perfected this cuisine.

Likewise, 10 Mexican kitchens from the following States were enlarged: Oaxaca, Michoacán, Puebla, Yucatán, Chiapas, Nayarit, Guerrero, CDMX, Colima and Veracruz, a crucial element of national identity, due to its history, creativity, diversity and transcendence, a of the people who made this recognition possible by Gloria López Morales, Mexican writer, journalist and diplomat, as well as founder and president of the Conservatory of Mexican Gastronomic Culture (UNESCO advisory body). 


\section{Theoretical framework}

\section{Traditional cuisine}

In recent times, attempts have been made to define what is traditional cuisine? And in general, it has been considered as a middle-class kitchen, which differs from the haute cuisine of the rich and is consumed by the general population. But this kitchen evolves slowly and gradually in consideration of the contributions of technological developments, variations of tastes, fashions and innovations that each chef brings in his preparation. In any case, at all historical moments the existence of two antagonistic tendencies has been postulated: the first a constant and constant desire to modify and update the usual cuisine and a second, the strong idea of preserving the fundamental elements of a traditional kitchen.

Traditional cuisine, in turn, is studied and admired by culinary geniuses, who praise its past and try to preserve it against any change that threatens to distort it.

It must be recognized that there is a group of people indifferent to the quality of food and that they only eat to survive, ignoring the importance and pleasure of a varied diet linked to cultural tradition. One of the trends and tastes of current tourism is the appreciation of history, nature and the arts, which is linked to the enjoyment of good food and traditional drinks, prepared, based on local products, handmade and reproduced according recipes inherited by ancestors. This trend is a model of life of an intellectual and philosophical position that has no geographical boundaries and that only a powerful incentive helped by tourism can be achieved based on the creation and dissemination of gastronomic itineraries.

In this way we can find that our traditional markets that at one time were supplying places for local populations, have now become true tourist captors who seek to find in them the culinary delights and traditions of the localities. The kitchens found in these establishments are mostly served by the socalled traditional cooks, who are faithful to oral knowledge, execute the ancestral recipes learned daily in the family and that mostly obey gastronomic calendars according to production of seasonal food.
The current gastronomic markets seek continuous fluidity, constantly presenting "new" products, innovative dishes and unusual and original techniques, only to mark a supposed status in the diner, trends are shown as the future and new ways of preparing dishes They are constantly renewing themselves to continue in the tune of novelty, being part of a liquid consumerism, because such preparations and modern concepts proposed in restaurants and gastronomic spaces are so fleeting that they do not even allow to consolidate themselves in the tastes of the diners, who before the novelty in a hurry, they radically change their tastes and preferences to somehow continue to the vanguard and follow fashion.

It should be understood that trends have a decline and that gastronomic concepts have an expiration date, they no longer think about creating dishes that they like in the long term, chefs who create and follow trends can save themselves efforts and limit themselves to searching the dishes unprecedented the maximum impact to please their guests, because at the end of fashion will become obsolete before the entry of new trends.

The diners "conservatives prefer to delight in delicacies of the past for familiarity and the meanings conferred on them, becoming loyal and faithful lovers of traditional cuisine." Giving way to the cooks to continue preserving ancestral dishes. From this perspective, the ancestral dishes show a continuous recreation and development, as they are transformed over time, the change of techniques, the culinary miscegenation or the adoption of new ways of eating, resignifying the culinary of each country, preserving the heritage gastronomic, new values are given to flavors perceived by taste and translated directly into feeling.

The dish contains part of the history of a community and reflects in it the identity of the guests becoming a source of aesthetic, historical and heritage pleasure. Gastronomy is then heritage and faithful reflection of society, each element that integrates the kitchen and food, is loaded with symbolic meaning and a significant value for diners, cooks and conservative society. Such symbols manifested in the food show a social and cultural relationship of the history of a community, and are also an expression of the memories of lovers of traditional cuisine. 
The gastronomic heritage is preserved through an awareness of the historical value of the dishes, and thanks to the readjustment of contemporary preparations combining flavors of the past and impressions of the present, the culinary traditions of the cuisine are preserved and kept alive antiquity. The kitchen presents a particular perspective on the transformations in society's relations with nature. However, although cooking is a privileged space for cultural reproduction, academics often overlook it, partly because of its difficult access, particularly for male researchers, but also because of the undervaluation of this space.

The idea that food is made with love and that it is an expression of love is not expressed only in Mexican culture - see, for example, Italian or Jewish culture. In its current form in the valley of Mexico it has roots in the preHispanic Mesoamerican culture. Particularly when cooking with corn and making tamales the sacred food of the gods - cooks have to respect certain rituals that reflect traditional beliefs.

\section{Professional Certifications}

One of the important issues today, apart from the concern that exists about how the worker acquires the necessary skills to deal with the transformations of the world of work, is the certification of those skills.

In recent years, there are several factors that justify professional certification as one of the central themes of the debate in the field of training and work. The concern for the improvement of the quality of training, the constant need to adapt training systems to the transformation of the productive world, the concern for guaranteeing training systems that allow the acquisition of skills that improve the flexibility and versatility of workers and the pertinent management of both labor and training mobility are some of the reflections that this debate is generating on the competences and their certification

The National Council for the Standardization and Certification of Labor Competencies (CONOCER) defines as competence the set of skills, abilities, knowledge and attitudes that are assertively specified in the resolution of problems or in a relevant response to a new or specific situation.
It also describes us as a standard of competence to the set of knowledge, skills, abilities and behaviors that a person requires to perform activities with a high level of performance. With these two concepts we can establish that a certification of competencies recognizes the knowledge, know-how and know-how of a person regardless of the way in which he acquired that knowledge.

The certificate of competence is an official document where a person is credited as competent in accordance with the provisions of a competition standard; This certificate of competence is a document issued by the Ministry of Public Education of the Federal Government in which it is ensured that the performance of a person conforms to what the companies or institutions require.

\section{Problem}

It is important to reflect on the complexity of the search for a certification system that serves as a basis for the recognition of the competences of those people who work in the service area; In this complex task, there are unresolved doubts at the moment about:

a) How do we build a certification model that is flexible enough to deal with the constant changes in context?

b) How can we certify competencies through a unique system, when the acquisition of those competencies in each area is different?

c) How are we going to consider, when certifying the competencies, those acquired throughout an active life, through work experience outside the training systems?

When we address the issue of professional certification, one of the first problems that arise is the diversity of terms that are used around the certification of competencies. Concepts such as recognition, accreditation, validation, certification, evaluation of professional competences, are often used interchangeably to refer to the same processes, those of certification and accreditation of competences, acquired in both formal and non-formal and informal situations. 
One of the most important factors is how the kitchen of each entity, must have recognition by the authorities, which must manage the necessary resources and policies that allow the preservation and conservation of the entity's gastronomy.

\section{Poblana Gastronomy Recognition}

The gastronomy of Puebla is recognized internationally for its flavor, its variety and its history. It is the result of the fusion of the culinary tradition of Mexican origin (prior to the colonial period) and the influences of Spanish, French and Arabic cuisine. Each of them contributed not only ingredients - such as tomatoes, onions, oil - but also utensils and processes that enriched the culinary offer of the state and considered one of the most representative of Mexico.

Living and tasting the typical poblano preparations present at different seasons of the year, knowing the stories that gave rise to them and that make them a national identity reference, are just a taste of the extensive meaning of a representative mestizo cuisine of the world, characterized by the merged vision of the ingredients between two gastronomic cultures: indigenous and European.

The gastronomy of Puebla was initially recognized through the communiqué shared by the National Council for Culture and the Arts on March 3, 2010, where the government of the state of Puebla declared it "Intangible Cultural Heritage of the entity", a title that was consolidated with the announcement of the United Nations Educational, Scientific and Cultural Organization (UNESCO) on November 16 of the same year, naming Mexican cuisine "Intangible Heritage of Humanity."

That is why based on Article 13 sections VII and VIII of the Internal Regulations of the Town Hall and Commissions of the Honorable City Council of the Municipality of Puebla; 7 section II, 11 sections I, III, XV and 12 sections XVI, XVII, of the Internal Regulations of the Secretariat of the City Council of the Municipality of Puebla, it is reported that in the Ordinary Session of the Cabildo, held on May 20,2019 , It is unanimously approved to vote on the establishment of May 17 as the "Municipal Day of the Traditional Cook and Cook"
This declaration was made with the objective of recognizing and valuing the gastronomic knowledge that is expressed in everyday practices and traditions, which are constantly recreated, in person, by experience and through oral communication.

The culinary culture is in the collective and nourished memory of knowledge and practices that come from the past. Therefore, the kitchen is always resignifying this legacy, which gives a sense of belonging to a community that has preserved its gastronomic traditions.

\section{Importance of certification of traditional cooks}

Traditional cuisine is understood as an exercise that manifests the memory in everyday practice, based on eating habits in which it allows the recognition of social life and the values that are assigned from it to the traditional; appropriate forms and recipes are built, it is mostly associated with the exercise of the commercialization and distribution of public spaces and events such as the Fairs and Meetings of Traditional Cuisine in which the purpose revolves around the conservation and enhancement of recipes and ingredients and as well as the local economy that have led to the development of food practices that clearly identify them.

The knowledge that traditional cooks have acquired through the years they have dedicated to preparing food can now be certified thanks to the integration of the new Competency Management Committee.

Because Gastronomy is much more than a recipe catalog or a restaurant directory. It is collectivity, it is history, myth, rite, legend, language, economy, market, exchange, community and symbolic values, religiosity and plastic: it is Culture. In this nature and with the importance given to our food and to the creators of these gastronomic ambassadors, as well as their knowledge and traditions; In order to have an instrument to certify the knowledge and work of people related to Traditional Cuisine, the Competency Management Committee of the Conservatory of Mexican Gastronomic Culture (CCGM) was integrated before the National Council for Standardization and Certification of Labor Skills (KNOW). 
This committee is made up of these agencies together with a representative from each state; with the purpose that this CCGM Competency Management Committee will be responsible for analyzing, identifying and developing competence standards and the instruments of competence assessment related to traditional cuisine, taking into account the need of people in training, evaluation and certification to increase your competitiveness.

\section{Traditional Poblana Cook Certification Model}

The certification of competencies for the traditional cooks of the state of Puebla, serves as an indicator that allows analyzing and evaluating the performance of their trade according to their knowledge and empirical experience in addition to practices of regional gastronomic traditions of Mexican cuisine, intangible cultural heritage.

\section{Traditional Poblana Cook Certification}

\section{I.- General Data Title Code CTP2019 Traditional poblana cook}

\section{Purpose of the Competition Standard}

Serve as a reference for the evaluation and certification of people who prepare food based on a recipe book (strong dishes, candy, drinks and snacks) and with utensils originating in traditional poblano cuisine.

It can also be the basis for the development of training and training programs based on Competency Standards (EC). This EC refers only to functions for which the realization of a professional title is not required by legal provision. Therefore, to be certified in this EC, it should not be a requirement to have said academic document.

\section{General Description of the Competition Standard}

This Standard of Competence, traditional poblana cook, describes the functions and competences of the traditional cooks of the state of Puebla, which perform their trade to the empirical knowledge and traditional experiences and practices that have been transmitted orally and according to the calendars state cuisine; which uses cooking techniques and methods, as well as utensils and original products.
This EC is based on guiding criteria of legality, competitiveness, free access, respect, decent work and social responsibility.

\section{Level in the National Competence System:}

Performs scheduled activities that are mostly routine and predictable. These activities have been learned orally and enriched by the daily life and knowledge of the products.

Requiring that these practices be considered as part of the system that make up the cultural and traditional knowledge of the population's identity. This Competition Standard, once published in the Official Gazette of the Federation, will be integrated into the National Register of Competition Standards operated by CONOCER in order to facilitate its use and free consultation.

\section{Organizations participating in the development of the Competence Standard}

- Conservatory of Mexican Gastronomic Culture.

- Relationship with other Competition Standards

- EC0042 Coordination of food and beverage services.

- $\quad$ EC0127 Food preparation.

- EC0128 Preparation of drinks.

- EC0081 Hygienic food handling.

It is recommended that the following aspects be considered in the evaluation:

a) The performance evaluation can be carried out in a real or simulated situation.

b) The products as a result of the requested performance will be presented as evidence during the evaluation of the Competition, so no history evidence is required.

\section{Elements that make up the Competition Standard}

Puebla gastronomic culture

PEREA-BALBUENA, José Ángel, CARRASCO-ROMERO, Víctor Josaphat and ZAMORA FERNANDEZ, María de los Dolores. Certification proposal for the traditional professional cook of the state of Puebla. RINOE Journal- Labor and Demographic economic. 2019 


\section{Evaluation criteria}

The person is competent when demonstrating the following:

\section{Performances}

1. The participants will distinguish the historical processes, analyzing the components that gave rise to the poblano cuisine and its identity according to the UNESCO criteria.

2. Participants will recognize the origin of the main food products and their geographical location.

3. Participants will identify the fusion of the various food items that gave rise to the main dishes of the poblana cuisine, according to Salvador Novo's studies.

4. The participants will relate historical events and events that initiated the legends of the main poblano dishes according to the studies of Artemio del Valle Arizpe and Enrique Cordero y Torres. following:

The person is competent when he has the

- Knowledge Recognizes historical processes that contribute to the culinary culture of Puebla.

- Recognize the importance of the fusion of food products created by the main dishes of Puebla.

\section{Supplies}

\section{Evaluation criteria}

The person is competent when demonstrating the following:

\section{Performances}

1. Knowledge

- Know the food products according to their origin.

- Know the use and use of seasonal products.

- Recognizes products according to their origin of production.
- Recognizes the organoleptic properties with respect to their lifespan.

The person is competent when he has the following knowledge:

1) Identify the food groups and their characteristics:

a. Cereals and tubers.

b. Fruits and vegetables.

c. Spices.

d. Product of animal origin.

2) Identify food products according to the agricultural cycle.

3) Recognize food products according to the geographical territory in which they are produced.

4) Identify according to flavors, smells and texture the feasibility of inputs for food processing.

\section{Utensils}

\section{Evaluation criteria}

The person is competent when demonstrating the following:

\section{Performances}

1. Origin and materials of traditional utensils.

- Identify the origin of traditional utensils.

- Identify the materials that make up the utensils for the preparation of traditional recipes.

2. Handling of traditional utensils.

- Know the proper way to handle the utensils to get the right products from the traditional recipe.

- Know the proper maintenance of traditional utensils. 
The person is competent when he has the following knowledge

1. Know the origin and materials that make up traditional utensils:

- Wood.

○ Mud.

○ Stone.

○ Metal.

○ Plant elements.

2. Identify the proper way to handle and care for traditional utensils

\section{Technique and methods for making} traditional dishes

\section{Evaluation criteria}

The person is competent when demonstrating the following:

\section{Performances}

1. Learn about the traditional techniques for the preparation of the main dishes of the poblana cuisine.

- Prepare the mise en place for various traditional dishes:

- Cutting the inputs as requested in the base recipe.

- Using the quantity of inputs required by the base recipe.

- Using traditional culinary techniques and methods

2. Prepare a main course:

- Applying culinary techniques established in the base recipe according to tradition.

- Applying the cooking method established in the base recipe.

3. Serve the main course:

- Using the weight established in the base recipe.
- Applying plating techniques according to the basic principles (color, texture, height, temperature and designs).

\section{Products}

\section{The requisition of inputs elaborated:}

- Includes recipe name.

- Contains quantity and unit of inputs according to the recipe.

The person is competent when he has the following knowledge:

- $\quad$ Meet traditional recipes.

- Use the appropriate percentages and weight with respect to the recipe.

- $\quad$ Process inputs with traditional culinary techniques and methods

\section{Results}

In order to be able to start the project of the "Traditional poblana cook" certification, a survey was conducted in the six main popular markets of the historic center of the city of Puebla (Alto, Parral, Acocota, El Carmen, de Sabores market); These markets are located in the most popular neighborhoods of the historic center, so it was considered that they would provide a perspective of the cooking of the traditional food that is sold in them. The survey was carried out taking 41 food service establishments as a sample.

The data sheet was made up of 9 items focused on knowing the culinary practice in these spaces: identify which are the traditional dishes that they prepare throughout the year (including temporary ones); the techniques, methods and tools implemented; origin of the recipes consulted for the preparation of dishes; places where inputs are acquired; and if the traditional cooks have knowledge in the history of poblano cuisine and food preparation. 


\section{Traditional dishes}

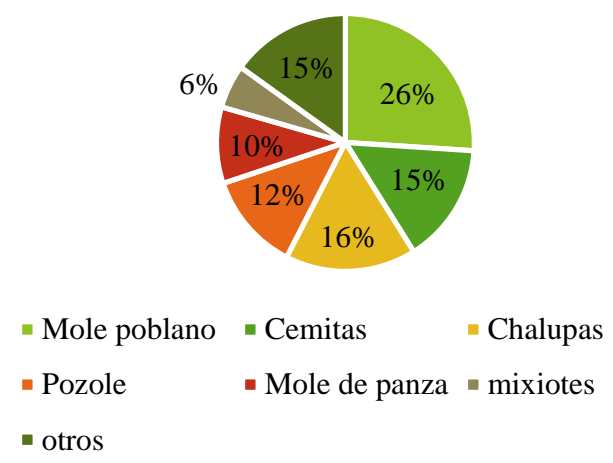

Graphic 1 Traditional dishes elaborated in the markets of the historic center of Puebla

Source: self made

The data collection highlights that $93 \%$ of the cooks prepare traditional dishes, where the mole poblano $(26 \%)$, cemita $(15 \%)$, chalupa $(16 \%)$, pozole $(12 \%)$ and the mole of belly stand out $(10 \%)$ representing $79 \%$ of traditional culinary production in the historic downtown markets.

\section{Seasonal Cymbals}

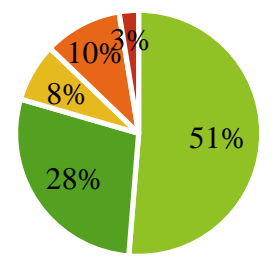

$$
\begin{aligned}
& - \text { Chile en nogada } \quad-\text { Tortas de camarón } \\
& - \text { Huaxontle } \quad-\text { Mole de caderas } \\
& - \text { Romeritos }
\end{aligned}
$$

\section{Graphic 2 Seasonal Cymbals}

Source: self made

The gastronomy of Puebla stands out for its wide variety of dishes present throughout the year, those so-called temporary are integrated into its recipes food supplies that are obtained only at precise times of the year. Chili in nogada with $51 \%$ presence in popular markets, followed by shrimp cake $(28 \%)$ and mole de hips (10\%).

\section{Capacitación de "Historia de la cocina poblana"}

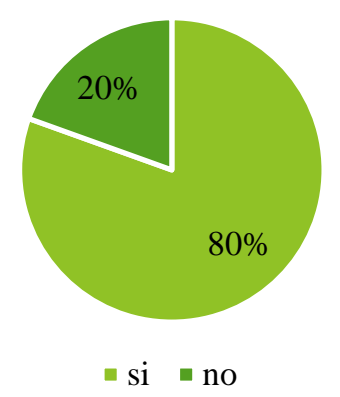

Graphic 3 Interest in the training of "History of poblana cuisine"

Source: self made

\section{Capacitación "Preparación de alimentos"}

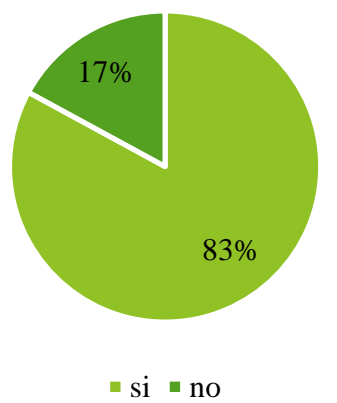

Graphic 4 Interest in the "Food Preparation" training Source: self made

As part of this study, the training of traditional cooks was considered, the group analyzed showed that $80 \%$ of the cooks show interest in taking training on the history of poblano cuisine and $83 \%$ in food preparation.

\section{Conclusions}

Puebla, in the viceregal era was a place of convergence, its gastronomy reveals the richness of the markets of "both seas". Conventual heritage, poblano cuisine allows the full enjoyment of being, that is, traditional dishes are lived through their colorful colors, stimulating smells, intense flavors and imagination through happy spirits, which converge on the table. The culinary heritage is set with the presence of indigenous, mestizo and Creole cuisine, which allows a unique symbiosis of flavors, where you dance between sweet, salty and spicy. The poblano kitchen in turn has created its own utensils (metates, molcajetes, sieves, sifters and casseroles of the neighborhood of the light, as well as its elegant crockery tableware. 
These knowledge and knowledge have been inherited from the traditional cooks from generation to generation, who, faithful to the old standards, take care of the culinary work of the people. Given the ties of the new kitchen trends, it is necessary to take care of this traditional knowledge of the cooks, which offer stews especially in the markets of the city. Therefore, training and recognizing their knowledge through an official certification will put their knowledge in quality; The purpose of this proposal is for this group of traditional cooks to continue promoting their knowledge and making themselves available to tourism, so that we can take care of the gastronomic heritage of this city and at the same time offer better working conditions to the guardians of an ancestral culture.

\section{References}

Arana, G. (2012). Los espacios de la cocina mexicana al albor del siglo XX. La creación alquímica de olores, sabores y texturas. Apuntes, vol. 25, núm. 1, 36-49.

CONACULTA. (S.F.). Patrimonio Cultural y Turismo. Cuadernos 12 El mole en la ruta de los dioses. 60 Congreso sobre Patrimonio Gastronómico y Turísmo Cultural (Puebla 2004). México: México .

Curiel Monteagudo, J. L. (2007). La mesa de Hernan Cortes. México: Porrua .

Di Clemente, E., Hernández, J., \& LópezGúzman, T. (2014). La gastronomía como patrimonio cultural y motor del desarrollo turístico. Un análisis DAFO para Extremadur. Monografía, no. 9, 817-833.

Gironella de Angeli, A. (2014). Larousse de la cocina mexicana. México: Ediciones Larousse .

Iturriaga, J. (2012). La cocina mexicana, patrimonio cultural de la humanidad . En G. Ponce, \& L. (. Rubio, Gestión del patrimonio arquitéctonio, cultural y medioambiental: enfoques y casos prácticos (págs. 153-158). Universidad de Alicante.

Mélendez, J., \& Cañez, G. (2010). La cocina tradicional como un elemento de identidad y desarrollo local. El caso de San Pedro El Saucito, Sonora, México. Estudios Sociales, no. 1, 182204.
Novo, S. (1979). Cocina Mexicana. Distrito Federal : Editorial Porrúa.

Reyes, A. (2015). Memorias de cocina y bodega. Barcelona : Editorial comba .

Urquiza, I. (2012). Cocina mexicana : patrimonio de la humanidad. México : Ediciones Larousse.

Voth, A. (2012). Patrimonio gastronómico, paisaje culturak y desarrollo rural: la revaloración de la cultura de la Sidra en Europa. En Buena, R., C. Foronda, L. Galindo, A. García, A. B. García, . . . C. Posada, Investigando en rural (págs. 581-592). Navarra: Elzama Ediciones. 